\title{
Antonina Kozyrska, Pluralizm wyznaniowy a integracja narodu ukraińskiego po 1991 roku [Religious Pluralism and the Integration of Ukrainian Nation after 1991], Europejskie Centrum Edukacyjne, Toruń 2015, pp. 451
}

The author of the monograph under review is a graduate of the Faculty of Theology of the John Paul II Catholic University of Lublin. In 2003, she obtained a PhD degree in humanities on the basis of her thesis Arcybiskup Edward Ropp (1851-1939). Życie i działalność [Archbishop Edward Ropp (1851-1939). Life and Activity]. Antonina Kozyrska's main research interests include issues concerning religious, ethnic and cultural relations in the region of Eastern Europe, especially Ukraine. The author's high scholarly status is confirmed by her activity in the national and international scientific debate and her participation in the activities aimed at the general public, implemented in the form of speeches delivered at several dozen scientific conferences organised by reputed universities in Poland (Warszawa, Poznań, Wrocław, Lublin, Kraków), and in Ukraine, Russia, Latvia, and Belarus.

Antonina Kozyrska is the author of over 50 scientific publications. They include two monographs, journal papers, monograph chapters, source documents, communications and encyclopaedic entries.

Antonina Kozyrska's book entitled Religious Pluralism and the Integration of Ukrainian Nation after 1991 is the crowning achievement of reliable scientific research. I am of the opinion that the author addresses an issue which is very important both from the cognitive and practical point of view.

Faculty of Political Science and International Relations, Nicolaus Copernicus University in Toruń, Poland, E-MAIL: kawadj@box43.pl. 
The work is an in-depth, competent and precise study in which the author deals with the influence of religious pluralism after 1991 on contemporary socialpolitical processes in Ukraine, particularly on the unity of the Ukrainian people. What must be emphasised is the fact that A. Kostyrska presents pluralism from a broad perspective, in the institutional (multitude) and theoretical dimension (legal model). She also presents it on the factual level, indicating social recognition and acceptance.

What should be stressed is the fact that not only does Antonina Kozyrska critically examine particular problems, but she has also grasped an extremely important skill of synthesising multi-aspect relations and phenomena, particularly in the political science, social and psychological dimension. What is more, the author's conclusions and judgments show her as an objective researcher.

The publication under review has an exceptionally clear, well thought out and logically cohesive structure. The layout of the monograph is correct from the perspective of the construction of a scientific dissertation. The title of the book accurately reflects the subject of deliberations.

The elaborate introduction includes all necessary components. The author provides definitions of key concepts, such as "religious pluralism”, "Ukrainian people”, or 'integration". She also indicates research methods applied in her work and identifies the goal of her deliberations. Defining the goal of her work, Antonina Kozyrska describes the phenomenon of religious pluralism in Ukraine and analyses its influence on the internal integration of the Ukrainian people after 1991. According to Kosturska, "a cultural and religious mosaic is a daily phenomenon in the Ukrainian land, and it is also part of the identity of contemporary Ukrainians” (p. 371).

The research hypothesis formulated in the introduction is elaborated through formulating five basic research questions: 1) what are the causes of the Ukrainian people's internal integration after 1991; 2) what is the specific nature of the religious structure of Ukraine and does the state of relations between the representatives of various churches, denominations and religions contribute to the unification of Ukrainian citizens; 3 ) is the legal (theoretical) model of religious pluralism reflected in the actual social status of individual churches and religious associations, especially in the context of their participation in the social and political life of Ukraine; 4) has the popular idea of the creation of a single Orthodox local church in Ukraine influenced the process of the internal integration of the nation; 5) has the role of the Church in the integration process in Ukraine after 1991 been different than it used to be in previous historical periods?

The book under review consists of five chapters, each of which has its own complex taxonomy. The book is supplemented with the list of abbreviations, the 
appendix, the abstract in the Ukrainian and Russian language, and - which should be stressed - the list of people.

Chapter one of the work discusses the function of religion in the life of contemporary nations, indicating, among others, the functions of: the stabilisation of group unity, social control, identity, identification and the legitimisation of the law. Kozyrska notes that "pluralism is part of the characteristics of late-modern societies. Its rise is the result of a number of socio-political and cultural phenomena that have occurred in the world over the last two centuries. It is a consequence of the diminishing role of state and national churches when it comes to integration and of the introduction of the principle of the separation of church and state, freedom of religion and equality of all religions” (p. 42).

In chapter two, the author reflects on the issue of national and religious regeneration in Ukraine in the transformation period. She points out that the process of the consolidation of national unity after 1991 was hindered by the significant pluralism of the society in terms of ethnicity, language, culture, as well as religion. What is equally important, the situation was even more difficult due to the "negative consequences of Soviet heritage [and] dilemmas concerning the choice of the model of the nation and of the direction of the state's development” (p. 97).

Chapter three of the monograph is devoted to the presentation of the development of religious structure in Ukraine. Antonina Kozyrska notes that this structure has evolved throughout ages, reflecting complex religious, socio-political and demographic phenomena that have taken place in the country. She also points out that, at the end of the $20^{\text {th }}$ century, we observed the dynamic growth of religious pluralism of the institutional character. The author adds that the religious structure in Ukraine in the period of system transformations was subject to volatility (p. 161).

In chapter four, A. Kozyrska looks into the participation of churches and denominations in social and political life. In this part of the work, the author examines both the legal model of religious pluralism, changes in the sphere of religious policy, the social activity of religious organisations, the religious factor in the activity of political parties, and, finally, the involvement of churches in the electoral process.

The last chapter of the monograph presents the problem connected with the implementation of the Ukrainian national project, with special attention paid to the ideal of Orthodox Ukrainian local church, which dates back to the 1990s.

It must be emphasised that what is an undeniable value of the monograph is its solid and diverse, interdisciplinary source base, which is supplemented by a broad body of foreign literature being the result of a thorough preliminary research conducted in Poland and abroad. Antonina Kozyrska polemically uses theoretical 
works in the field of history, political science and religious studies. She also refers to statistical materials. Doing this, she makes use of her scientific competence and follows methodological guidelines in the field of political science.

What is another merit of the publication is its highly erudite, and at the same time communicative language (although the text is not free of some minor stylistic shortcomings). The author has mastered a skill of describing and defining difficult problems and issues in a comprehensible way. What is important, the work was written in a very interesting and accessible way, with the use of professional terminology.

To sum up, it should be emphasised that Antonina Kozyrska's book concerns problems that have not yet been addressed with sufficient attention in the literature of political science. In my view, it is an engrossing study that should be of particular interest for researchers dealing with religious and ethnic relations, and with the issue of the identity of post-communist societies. There is no doubt that it may also be an inspiration for students of international relations, political science or Eastern studies. 